Discussion Paper No. 15-046

Revenue Decentralization, Central Oversight and the Political Budget Cycle: Evidence from Israel

Thushyanthan Baskaran, Sebastian Blesse, Adi Brender, and Yaniv Reingewertz

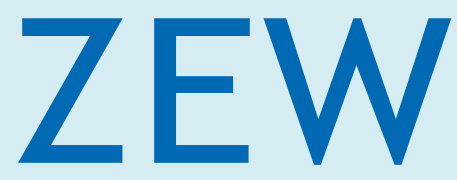

Zentrum für Europäische Wirtschaftsforschung $\mathrm{GmbH}$

Centre for European Economic Research 
Discussion Paper No. 15-046

\title{
Revenue Decentralization, Central Oversight and the Political Budget Cycle: Evidence from Israel
}

\author{
Thushyanthan Baskaran, Sebastian Blesse, \\ Adi Brender, and Yaniv Reingewertz
}

Download this ZEW Discussion Paper from our ftp server:

http://ftp.zew.de/pub/zew-docs/dp/dp15046.pdf

Die Discussion Papers dienen einer möglichst schnellen Verbreitung von neueren Forschungsarbeiten des ZEW. Die Beiträge liegen in alleiniger Verantwortung der Autoren und stellen nicht notwendigerweise die Meinung des ZEW dar.

Discussion Papers are intended to make results of ZEW research promptly available to other economists in order to encourage discussion and suggestions for revisions. The authors are solely responsible for the contents which do not necessarily represent the opinion of the ZEW. 


\title{
Revenue decentralization, central oversight and the political budget cycle: Evidence from Israel
}

\author{
Thushyanthan Baskaran (University of Goettingen) \\ Sebastian Blesse (ZEW and University of Frankfurt) \\ Adi Brender (Bank of Israel) \\ Yaniv Reingewertz (University of Haifa) ${ }^{1}$
}

\begin{abstract}
This paper examines whether revenue decentralization and direct external financial supervision affect the incidence and strength of political budget cycles, using a panel of Israeli municipalities during the period 1999-2009. We find that high dependence on central government transfers-as reflected in a low share of locally raised revenues in the municipality's budget-exacerbates political budget cycles, while tight monitoring-exercised through central government appointment of external accountants to debt accumulating municipalities-eliminates them. These results suggest that political budget cycles can result from fiscal institutions that create soft budget constraints: that is, where incumbents and rational voters can expect that the costs of pre-election expansions will be partly covered later by the central government.
\end{abstract}

Keywords: Political budget cycles; soft budget constraint; local governments; decentralization JEL codes: D72, H72, H74, E62

1 Corresponding author, Address: 199 Aba Koushy Blvd., Haifa, Israel; Tel.: +972-48249089; Email: yanivrein@poli.haifa.ac.il. We would like to thank seminar participants at the Hebrew University of Jerusalem, Bar Ilan University, the Research Department at the Bank of Israel and the European Public Choice Society annual meeting. We would also like to thank Esteban Klor, Avi Ben Bassat, Momi Dahan, and Oded Steklov for their comments and suggestions and Meir Dubitsky for editorial assistance. Lili Feintuch, Dudi Sapir and Yuval Levy from the Israeli Ministry of Interior Affairs graciously provided us the data. 


\section{Introduction}

A wide body of political economy literature debates the existence and potential determinants of political budget cycles - broadly defined as the manipulation of fiscal policy by incumbent politicians, and in particular accumulation of deficits - when an election is imminent (Drazen, 2008; Alesina, 1989; Alesina et al., 1993; Akhmedov and Zhuavskaya, 2004). According to theoretical contributions, electoral manipulation of fiscal policy can be effective in contexts where voters are not fully rational (Nordhaus, 1975) or imperfectly informed (Brender and Drazen, 2005; Shi and Svensson, 2006; Alt and Lassen, 2006), or where economic cycles induced by the manipulation of fiscal variables can serve as a signal of the incumbent government's competence (Cukierman and Meltzer, 1986; Rogoff and Siber, 1988; Rogoff, 1990). As distortions in fiscal policy for purely electoral reasons may have significant economic costs, it is important to understand under what conditions such manipulation is most likely to occur.

A widely cited factor affecting the tendency of politicians to generate political budget cycles is the lack of accurate real-time information for voters regarding the status of public finances and the economy (Drazen, 2008; Eslava, 2011). The relevance of such information stems from the argument, supported by empirical evidence (e.g., Brender and Drazen, 2008; Brender, 2003), that if voters are aware of the manipulation they might actually "punish" the incumbent at the polls, recognizing the inefficiencies caused by the manipulation.

In this paper, we examine the possibility that if some of the costs of electoral fiscal manipulations could be shifted outside the jurisdiction - e.g. to the central government - it may affect voters' attitudes towards the manipulation and, accordingly, the tendency of local policy 
makers to induce political budget cycles. This possibility may explain why political budget cycles are more commonly found to exist in subnational elections ${ }^{2}$, than in national ones. We thus study how revenue decentralization, reflected in the share of locally generated revenues, affects the incidence of political budget cycles. For that purpose we use dynamic analysis of a panel of Israeli municipalities over the period 1999-2009. We focus on two institutional characteristics that were simultaneously present during this period: the degree of revenue decentralization and whether the municipality was subjected to tight central oversight exercised by the appointment of external accountants by the central government.

Regarding the degree of self-financing, the respective figures vary among Israeli municipalities. While some finance their expenses mostly with locally raised revenues, many rely heavily on central government transfers. We hypothesize that the incentives to run deficits for electoral reasons are lower in municipalities that rely strongly on locally raised revenues, presumably because voters are aware that deficits imply higher local taxes or curtailed services in the future. Local politicians in such municipalities may thus anticipate that deficits will not lead to electoral rewards (Brender, 2003). In contrast, politicians and voters in municipalities that rely on central transfers may reasonably expect that deficits will induce higher transfers in the future (Meloni and Tommasi, 2012). The possibility to have the central government and thus the fiscal commons cover deficits may facilitate overspending and specifically the emergence of political budget cycles (Weingast et al., 1981).

As for central government monitoring, from 2003 onward the Israeli central government appointed external accountants to several highly indebted municipalities and to municipalities that were poorly managed financially. These accountants had the special authority to monitor

2 Studies that examined this issue at the subnational level include Blais and Nadeau (1992), Galli and Rossi (2002), Khemani (2004), Akhmedov and Zhuavskaya (2004), Coelho et al. (2006), Veiga and Veiga (2007), Cole (2009), Aidt et al. (2011), Dahlberg and Mörk ( 2011), Foremny et al. (2014), Tepe and Vanhuysse ( 2014) and Baskaran et al. (2015). 
fiscal policy operations, and in particular to stop payment in cases of deficits. It is likely that such central oversight limits the ability of municipalities to generate electoral cycles in fiscal policy, or at least increases the likelihood that such attempts will be exposed in real-time. We therefore control for this effect, as it may be negatively correlated with the magnitude of the political budget cycles, as well as with the share of locally generated revenues. ${ }^{3}$ However, based on past limited success with alternative measures, e.g., a ban on bank borrowing without ministerial approval, reporting requirements and recovery programs, it is also possible that municipalities are able to evade the supervision and accumulate deficits during election years despite the central oversight.

Our empirical results suggest that significant political budget cycles exist in Israeli local elections: controlling for the other variables, municipal deficits are on average 8 percentage points larger in local election years than in other years. However, further analysis also shows that cycles are less pronounced in municipalities that rely mostly on locally raised revenues, and do not exist in those subject to centrally appointed accountants. These findings imply that deficits are likely associated with electoral costs for local politicians if they may lead to higher taxes in the future. Previous empirical support for this notion is offered by Brender (2003) and Drazen and Eslava (2010), who find that deficits indeed lead to electoral losses in Israeli and Colombian local elections, respectively. We find, first, that low dependence on central transfers dampens political budget cycles, but they remain significant. Second, enforced control by the central government through external accountants turns political budget cycles statistically insignificant. Our results thus imply that either strong central oversight or significant revenue decentralization can limit opportunistic behavior by incumbent local governments. The worst

\footnotetext{
${ }^{3}$ The mean share of locally generated revenues in total revenues among localities that had an external accountant was $51 \%$ and among those that did not have one it was $61 \%$. There is a broad range of overlap between the two groups with respect to the share of locally generated revenues.
} 
institutional setup appears to be when a high degree of local fiscal autonomy is combined with strong reliance on central transfers.

Our contribution to the literature is in exploring the role of fiscal decentralization and soft budget constraints as potential determinants of political budget cycles. Several other potential determinants have previously been discussed in the literature. Brender and Drazen (2005), for example, study whether the incidence of political budget cycles differs between new and established democracies. Their results indicate that experience with democratic politics and the quality of information as well as information transmission are important conditioning factors for the existence of the cycles. Furthermore, fiscal rules have been found to be important for the strength of political budget cycles (Rose, 2006). Another factor that may affect the incidence of political budget cycles is the existence of term limits for elected politicians (Klein and Sakurai, 2015). While such determinants of political budget cycles have been discussed in the literature ${ }^{4}$, the impact of fiscal decentralization and central government oversight, the main focus of our study, remains largely unexplored. ${ }^{5}$

The second branch of the literature to which our paper contributes is the fiscal federalism literature on the link between intergovernmental transfers and subnational borrowing. Many theoretical contributions suggest that reliance on central transfers creates undesirable incentives for subnational governments and may lead them to over-borrow. Specifically, if local governments expect that deficits in the current period will cause the central government to increase transfers in the future, incentives to run prudent fiscal policies will be diminished,

\footnotetext{
${ }^{4}$ See also for other possible determinants Nie et al. (2013) who find that the amplitude of any electoral cycle depends inter alia on media exposure, and Schneider (2010) who argues that the degree of fiscal transparency matters. De Haan and Klomp (2013) provide a recent survey of the literature on the determinants of political business cycles.

${ }^{5}$ Meloni and Tommasi (2012) show in a related study for Argentina that reliance on central transfers causes voters to demand more spending (a finding replicated in our results below, that higher locally raised revenues are associated with smaller per-capita deficits). However, they do not focus on the interactions between fiscal dependence and political budget cycles. Instead, the argument is used to explain the finding that higher deficits result in electoral gains in Argentina.
} 
leading to soft budget constraints and subnational over-borrowing (Kornai, 1979; Kornai, 1986;

Rodden, 2002; Rodden et al., 2003). Our results support these theoretical predictions by showing that Israeli local governments which rely on transfers are more likely to run deficits in general (controlling for local characteristics that may account for both larger transfers and deficits), as well as for electoral reasons. Our results hence add to previous empirical findings on the link between intergovernmental transfers and soft budget constraints in fiscal federations. Pettersson-Lidbom (2010), for example, shows that expected future transfers may lead to subnational over-borrowing in Swedish municipalities. Baskaran (2012) reaches a similar conclusion for the German Länder. Sola and Palomba (2015) find that capital markets, when pricing the risk premia of subnational governments, are less responsive to fiscal fundamentals when soft budget constraints, in the form of higher shares of central government transfers, exist. However, these studies neither focus on elections nor tie soft budget constraints to political budget cycles. Thus, to our knowledge, our paper is the first to show empirically that ill-designed fiscal federalism institutions can exacerbate the fiscal inefficiencies typically associated with electoral manipulation.

The remainder of this paper is structured as follows. The next section describes the fiscal and political institutions at the local level in Israel. Section 3 discusses the empirical framework and data. The results are reported in Section 4, and Section 5 concludes.

\section{Institutional details}

Our empirical analysis deals with Israeli municipalities during the years 1999-2009. In 2009, there were 200 municipalities in Israel. ${ }^{6}$ One hundred and twenty municipalities were

\footnotetext{
${ }^{6}$ The analysis does not include the 54 regional municipalities. This is because the political system in regional municipalities operates differently than in local municipalities. Regional municipalities are comprised of several settlements, each receiving a seat on the council. In addition, the number of municipalities changed in 2003 
predominantly comprised of Jewish residents, while 80 had a majority of Arab residents. This classification is important since Jewish and Arab municipalities are very different both economically and politically. First, Arab municipalities tend to be much poorer than Jewish ones (Reingewertz, 2015) and, hence, rely more heavily on central government transfers. They also tend to have higher debt levels and therefore face stricter central government monitoring, including the appointment of external accountants (Ben Bassat et al., 2013). Second, voters in Arab municipalities were found to vote according to clan affiliation (Ben Bassat and Dahan 2012; Reingewertz, 2015; Hillman et al., 2015), rather than according to local government performance. These characteristics imply that the Arab municipalities are less relevant to the questions we study. Thus, we focus on the 120 Jewish municipalities, of which 6 were subject to a population composition change as a result of centrally enforced amalgamation. Therefore, our final sample includes 114 municipalities.

The average municipal population in our sample is 31,000 , but population sizes vary considerably and range from 1,300 to 748,000 residents. Local governments in Israel, much like in most other developed economies, provide various municipal services, such as garbage collection, lighting, and sewage. In addition, Israeli municipalities are in charge of education provision (funded predominantly by specific transfers from the central government), road maintenance, and, partly, welfare. In 2007, 7\% of GDP was spent by local governments, accounting for about $15 \%$ of total public expenditure. About $65 \%$ of municipal revenues came from taxation and other locally generated resources. The remaining 35\% were grants from the central government. The extent to which a municipality relies on grant funding is highly dependent on its socioeconomic status: municipalities with low socioeconomic status tend to rely on government transfers much more than their rich counterparts. Since the socioeconomic municipalities that were affected by the amalgamation of 2003 (Modiin, Yehud-Monoson, Binyamina-Givat Ada, Kadima-Tzoran, Kochav Yair, Savion). 
status of localities is almost fixed over time, we control for it by using a municipality fixed effect in our econometric estimation below.

The political system at the local level is only partially linked to the national level. Local candidates are usually not tied to national parties; the agenda in local elections is usually not focused on national-partisan topics, and focuses on local issues. Moreover, local results do not mirror national results (Diskin and Eden, 1999). The elections are held using two ballots: one for the mayor and one for the party in the local council. This creates a presidential system where the budget is prepared by the mayor but has to be approved by the council. The mayor holds considerable power, but the local council acts as a veto player that can block budget proposals (Brender, 2003; Diskin and Eden, 1999).

Israel's intergovernmental relations are formally highly centralized. The central government determines a general annual change in local tax rates, approves each local decision to deviate from this rate, and has to approve the local budget. In addition, as mentioned above, many local governments depend on funding from the central level. However, effectively, the supervisory abilities of the Ministry of Interior at the specific locality level are limited, so the municipalities enjoy significant de facto autonomy, especially when they do not require special financial aid from the central government. Substantial reforms that were introduced from the mid-1990s have formalized the transfers, determining them predominantly according to objective criteria that are unrelated to the short-term fiscal performance of the municipalities (Brender, 2003). This was a major change from the past practice when annual changes in the transfers were based to a large extent on past deficits. Nevertheless, even today, some transfers are made where deficits emerge. When municipalities run into financial distress and need government support, the central government tends in many cases to apply "recovery programs", which may be demanding, in return for this aid. Recovery programs are specifically tailored to each 
municipality. They include two main components: an increase in central government transfers to reduce municipal debt, and a set of fiscal goals, such as maintaining a balanced budget through budget cuts and an increase in local tax collection. Despite these ambitious goals, in practice recovery programs do not have significant budgetary effects, except for debt reduction due to central government transfers (Ben Bassat et al., 2013).

One of the mechanisms used by the Ministry of Interior in order to regulate the activities of financially distressed or poorly managed local governments is the appointment of external accountants (Ben Bassat et al., 2013). Their responsibility is to oversee municipal fiscal policy, with the purpose of balancing the budget, rather than to dictate specific spending or revenue programs. ${ }^{7}$ The appointment of external accountants is a relatively new tool used by the Israeli central government that was introduced through legislative amendments adopted in 2003. External accountants have been shown to be an effective tool for fiscal restraint (Ben Bassat et al., 2013; Steklov, 2008) though their effect during election years remains unexplored.

\section{Empirical design and data}

\subsection{Data}

We use political, budgetary, and socioeconomic data of municipalities in Israel from 1999 to 2009. For the reasons outlined above, we focus on the Jewish municipalities. ${ }^{8}$ The data were obtained from publications of the Israel Central Bureau of Statistics (ICBS) and from administrative data provided by the Ministry of Interior (summary of the audited financial data of the Municipalities’ Audit Department, various years). In Table 1 we report a list of the main

\footnotetext{
${ }^{7}$ In the most extreme cases the central government demotes the elected local government and nominates a convened committee. A convened committee is a bureaucratic committee, appointed by the central government, which replaces the mayor.

${ }^{8}$ As shown in Table 6 the results are qualitatively unaffected when we analyze Jewish and Arab municipalities jointly.
} 
variables and their definitions. Election data were also collected from the Ministry of Interior (Elections Supervision Unit). Local elections take place every five years, with 2003 and 2008 being the election years in our sample. Due to various reasons, some municipalities had elections on other dates. ${ }^{9}$ Since the change in election date is potentially endogenous to the financial situation of the municipality, and because "convened committees" are irrelevant for the question we examine, we exclude these cases from the sample. We also drop six municipalities that were subject to amalgamations. Thus, of a total of 120 Jewish municipalities, our final sample includes 114 municipalities.

The dependent variable is the annual per-capita deficit, defined as the percentage change in debt per-capita. The main independent variables of interest are the dummies for local elections and their interactions. The two local election campaigns were held in November 2003 and 2008, i.e., towards the end of the fiscal year. Further important variables are a variable measuring the degree of revenue decentralization, i.e.. the share of locally generated revenues in total revenues of the municipality (“own revenues”) and a dummy for whether a municipality had an external accountant.

As additional covariates that may affect both the main variables of interest and deficits, we always include the number of inhabitants in a municipality, the local unemployment rate, a dummy for whether or not a municipality has a high level of debt (higher debt per-capita than the respective median municipality), and the volume of central government transfers per-capita. We also control for the lagged dependent variable. ${ }^{10}$

\footnotetext{
${ }^{9}$ Some municipalities were managed by a "convened committee". In these cases elections were held when the term of the convened committee ends and not on the same date as the national cycle.

${ }^{10}$ Robustness tests with respect to these specifications are reported in Table 7.
} 
Table 2 presents summary statistics for the main variables used in the analysis. Local authorities have an average surplus of 0.024 , i.e., they reduce their debt per-capita by 2.4 percent annually on average, but the standard error is 0.154 , showing the large variance in deficits across municipalities. To account for outliers, we drop the top and bottom $1 \%$ for the deficit variable when calculating the summary statistics, i.e. all observations below the 1st and above the 99th percentile. We also omit these outliers in the regression analysis presented below.

Table 2 furthermore shows that about 8 percent of observations were subject to an external accountant during the sample period. The average share of "own revenues" was about 60 percent, but there is again significant variation across municipalities - the highest own revenue share in our sample is 95 percent, while the lowest is 13 percent. There is also substantial variance in unemployment rates and transfer receipts between municipalities.

\subsection{Empirical model}

We examine the link between deficits and elections by analyzing a panel of Jewish municipalities for the years 1999-2009. The baseline model is as follows:

Equation (1):

$$
\begin{gathered}
\Delta \log (\text { debt })_{i, t}=\Delta \log (\text { debt })_{i, t-1}+\text { BElection }_{i, t}+\text { SExternal }_{i, t}+\varphi{\text { Own } \text { revenues }_{i, t}}+ \\
\gamma_{1} X_{i, t}+\gamma_{2} I_{t}+\alpha_{i}+\epsilon_{i, t}
\end{gathered}
$$

where $\Delta \log (d e b t)_{i, t}$ is the first difference of log debt per-capita of municipality i in year t, which is essentially the deficit. $\Delta \log (d e b t)_{i, t-1}$ is the lagged value of deficit; Election $_{i, t}$ is a dummy variable for the year local elections took place; External $_{i, t}$ is a dummy for municipalities that are subject to an external accountant, and Own revenues $s_{i, t}$ is the ratio of locally raised revenues to total revenues. As indicated above, the vector $X_{i, t}$ includes further 
control variables, specifically the number of inhabitants, the unemployment rate, the dummy for high debt, and equalization transfers from the central government, while $I_{t}$ is a trend variable to account for common developments regarding the deficit. ${ }^{11} \alpha_{i}$ are municipality fixed effects.

While the model specified in Equation (1) can be used to estimate the existence of political budget cycles, our main interest is to understand whether they are more pronounced under certain fiscal institutions, specifically when a municipality is characterized by a large share of “own revenues” or subject to tight external supervision. Thus, our main specification includes interaction terms between the election dummy and both the dummy for external accountants and the "own revenues" variable:

Equation (2):

$\Delta \log (\text { debt })_{i, t}=\Delta \log (\text { debt })_{i, t-1}+\beta$ Election $_{i, t}+\delta_{1}$ External $_{i, t}+\delta_{2}$ Election $_{i, t} \times$ External $_{i, t}+\varphi_{1}$ Own revenues $_{i, t}+\varphi_{2}$ Election $_{i, t} \times$ Own revenues $_{i, t}+\gamma_{1} X_{i, t}+\gamma_{2} I_{i, t}+$ $\alpha_{i}+\epsilon_{i, t}$,

where all the variables are defined as above.

\subsection{Estimation method}

While the above models include municipality fixed effects, it has been shown that the standard fixed effects estimator is biased when the model includes a lagged dependent variable (Nickell, 1981). Although the bias vanishes in large panels ( $T>30)$, our panel covers only about 10 years. Judson and Owen (1999) offer simulation evidence that the System-GMM estimator performs well for such samples (Blundell and Bond, 1998 and 2000). Thus, we use the System-GMM

\footnotetext{
${ }^{11}$ Note that we cannot include year dummies because the local elections in our sample are held in all municipalities at the same date.
} 
estimate as the main estimator; however, we also explore the robustness of the results to other estimation methods further below. The main feature of the System-GMM estimator is to instrument the lagged dependent variable with further lags of the dependent variable. In addition, it estimates Equation (2) both in level form and in first-differences to increase efficiency. For hypothesis tests, we always use cluster and heteroscedasticity robust standard errors. The unit of clustering is a given municipality.

\section{Results}

\subsection{Baseline results}

Figure 1 shows descriptive evidence regarding the existence of political budget cycles in Israeli municipalities. Comparing raw averages, we observe that average deficits are larger, by about five percentage points, in election years than in non-election years. However, it remains to be seen whether this result survives more rigorous tests. 
Figure 1. Average Municipal Deficit in Election and Non-election Years` ${ }^{\wedge} 1999-2009^{12}$

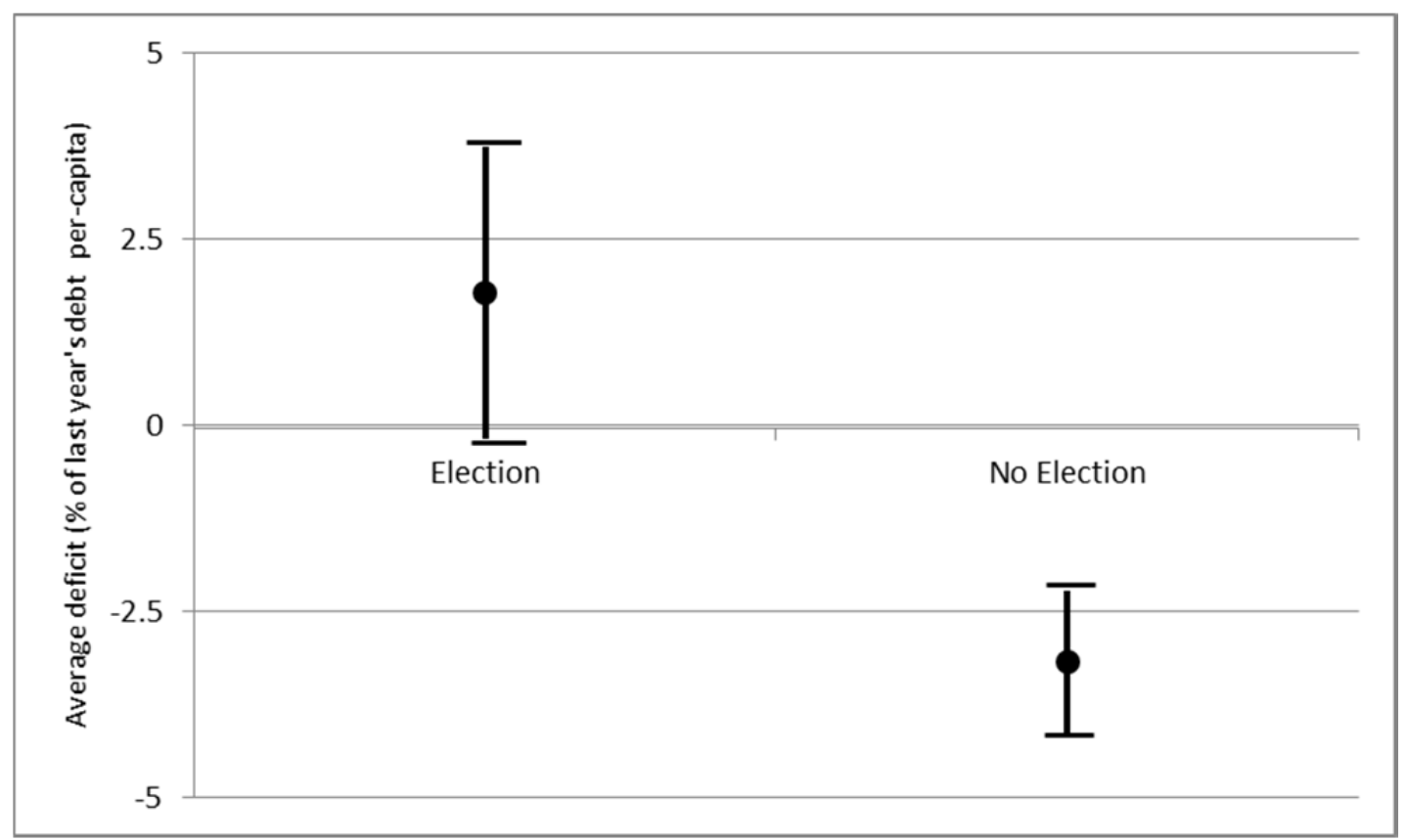

${ }^{\wedge}$ The upper and lower horizontal lines represent the 95\% confidence intervals.

Column (I) of Table 3 estimates a variant of Equation (1). Consistent with the graphical evidence presented above, we observe a significantly positive effect of elections on deficits. The growth rate of debt is on average about 8 percentage points higher in election years than in non-election years. We also find that external accountants lead to lower deficits: municipalities that are subject to an external accountant have on average a deficit that is about 8 percentage points lower. Finally, we find that an increase in the share of locally generated revenues by one percentage point on average decreases deficits by 0.18 percentage points. Thus, an increase in the "own revenues" share from 25\% to $75 \%$ would decrease deficits on average by about 9 percentage points

In Column (II) we include the interaction between external accountants and the election dummy. The interaction effect is significant and negative; suggesting that the electoral cycle is less pronounced in municipalities that have an appointed external accountant. We interpret this

\footnotetext{
${ }^{12}$ Figures are the simple averages of the change in all the localities in our sample.
} 
interaction effect in more detail below. First, however, we report in Column (III) results where we interact the "own revenues" variable with the election dummy. We again observe a significant interaction effect. In Model (IV), we include both interactions. The results are similar to those in Columns (II) and (III), respectively, and the coefficients of both interactions are not affected substantially by their joint inclusion in the equation. The diagnostic tests perform reasonably well in all models. The Hansen-J over-identification test is never rejected while there is also no evidence of second-order autocorrelation. First-order autocorrelation is expected and does not invalidate the estimates.

To interpret Table 3 (Model IV) in more detail, we plot in Figure 2 the marginal effect of elections on the percentage change of debt in municipalities with and without external accountants, depending on the share of locally raised revenues in their overall income ("own revenues”). ${ }^{13}$ Subfigure (a) suggests that elections have a significantly positive effect on deficits in municipalities without external accountants at all plausible levels of "own revenues" although the effect diminishes as "own revenues" increases. For example, in municipalities that would have the minimum "own revenues" share in our sample, which is about $13 \%$, deficits would be on average 17 percentage points higher during election years. In contrast, in municipalities that would have the highest revenues share, about $95 \%$, the election effect is about 4 percentage points. Thus, this plot indicates that revenue decentralization can dampen the political budget cycle substantially, but not fully eliminate it. Subfigure (b) suggests that where external accountants are nominated, the political budget cycle is essentially non-existent, as the marginal effect is not significantly larger than zero by statistical means at any level of "own revenues”. Specifically, while the election effect at the minimum value of "own revenues” is about 3 percentage points, it is about -10 at the maximum.

\footnotetext{
${ }^{13}$ For a discussion of how to present and interpret interaction models, see Brambor et al. (2006).
} 
Figure 2a. The Effect of Election Years and the Share of Locally Generated Revenues on Municipal Deficits: No External Accountant (ratio of previous year's debt per-capita)^

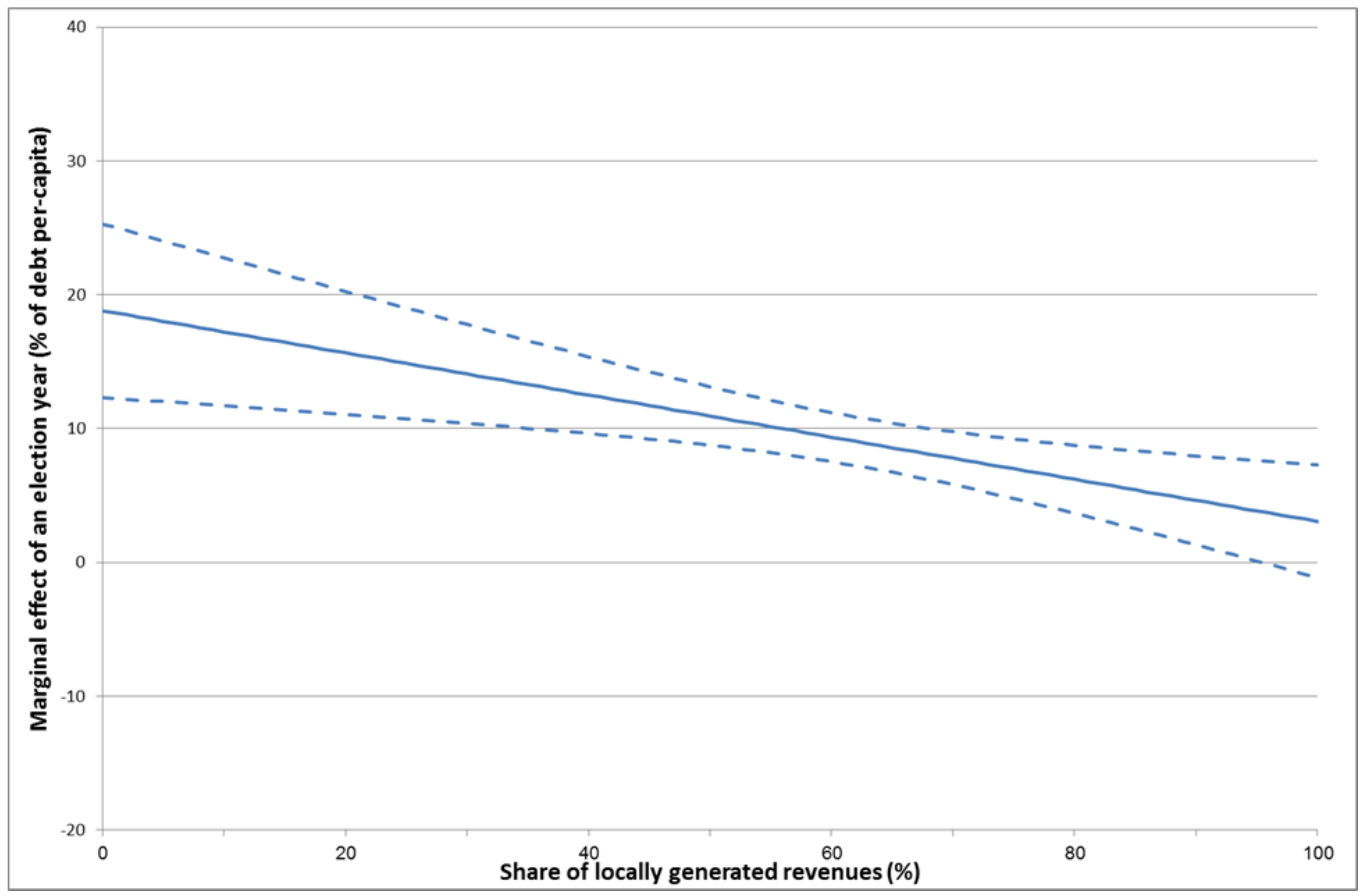

${ }^{\wedge}$ The upper and lower horizontal lines represent the $90 \%$ confidence intervals.

Figure 2b. The Effect of Election Years and the Share of Locally Generated Revenues on Municipal Deficits: With an External Accountant (ratio of previous year's debt per-capita) ${ }^{\wedge}$

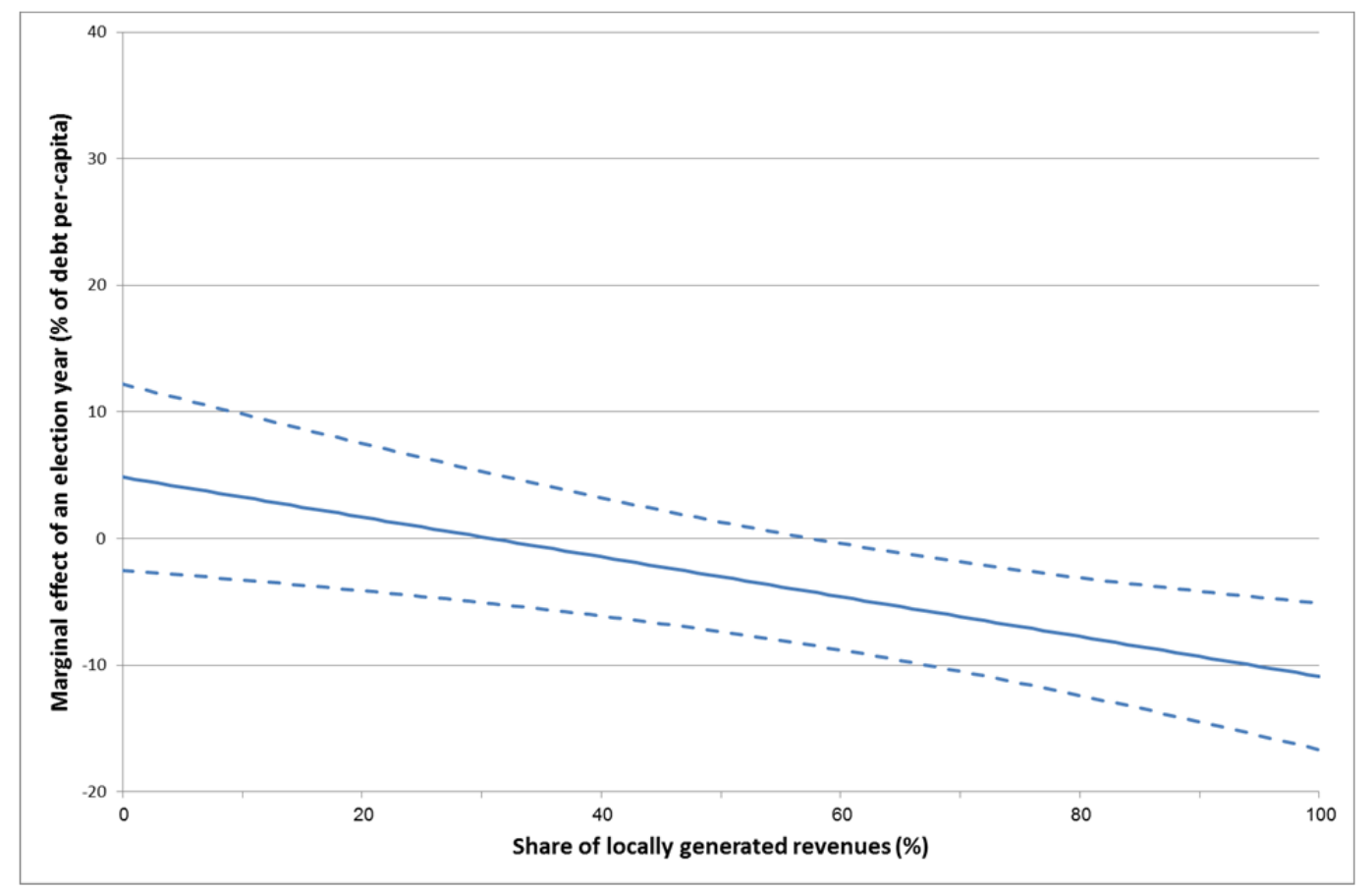

${ }^{\wedge}$ The upper and lower horizontal lines represent the $90 \%$ confidence intervals. 
While “own revenues” and external accountants reduce deficits particularly in election years, the results continue to suggest that both factors also have a dampening effect on deficits in general. That is, the "base" effect of both variables is significantly negative in Model (IV).

We also observe significant coefficients for the other covariates. First, there is some persistence in deficits. Municipalities that had a higher deficit in the previous year continue to have higher deficits in the current year. A higher unemployment rate increases the deficit (although the last two variables are not significant when we use the fixed effects estimation). A high stock of debt also leads to higher deficits, either because municipalities have to pay higher interest rates because the principal is higher - or because it reflects other unobservable characteristics related to the conduct of local fiscal policy. Transfers have a negative effect on deficits. Finally, there does not seem to be a common trend regarding the deficit during our sample period.

\subsection{Robustness tests}

\subsubsection{Other estimation methods}

In Table 4 we report results from a replication of the baseline models with estimation methods other than System-GMM with the full instrument set, notably the standard within fixed effects estimator, Anderson-Hsiao (Anderson and Hsiao, 1981), Difference-GMM (Arellano and Bond, 1991), and System-GMM with less than the full instrument set.

While less efficient than System-GMM, the advantage of the Anderson-Hsiao and Difference-GMM estimation methods is that they are less susceptible to the "too many instruments” problem (Roodman, 2008). In particular, the problem of instrument proliferation reflects the fact that with increasing instrument count the Hansen-J statistics become weak and 
unreliable, causing an over-rejection of the test for joint instrument validity. Similarly, the simple within fixed effects estimator is not affected by the instrument proliferation problem as it does not use any instruments. Despite being biased, this estimator may be informative as it is consistent for large T. Finally, another strategy to deal with instrument proliferation is to reduce the number of instruments within the System-GMM approach by either collapsing the instrument set or limiting the lag length.

Column (I) of Table 4 reports the results from the within-estimator. We find that the results are similar, both in magnitude and with respect to statistical significance, to the baseline findings. Column (II) collects the Anderson-Hsiao results. The Anderson-Hsiao first-differences model is similar to the empirical model as specified in Equation (2), but it uses as an instrument for the first-difference of the lagged dependent variable the second lag of the first difference. ${ }^{14}$ Thus, the Anderson-Hsiao estimator uses only one instrument. We again find that the results are in line with the baseline results. The interactions between the election dummy and both "own revenues” and the external accountants dummy are negative and significant.

The Difference-GMM estimator only uses one differenced version of Equation (2) to estimate the coefficients of interests. The Difference-GMM results are collected in Column (III) of Table 4. Note that the number of instruments is lower than in the System-GMM regressions. The results, however, are similar. While there is on average an electoral cycle in deficits, it is less pronounced in municipalities that have high "own revenues” and/or have an appointed external accountant.

\footnotetext{
${ }^{14}$ Another variant of the Anderson-Hsiao estimator uses the second lag of the level of the lagged dependent variable as the instrument. Note that we get similar results with this alternative Anderson-Hsiao estimator.
} 
Next, we collect in Column (IV) System-GMM regressions with a collapsed instrument set. Column (V) collects System-GMM results where the lag length is limited to the second lag of the dependent variable. Third, despite the well-performing Hansen-J and autocorrelation tests, the instruments for the lagged dependent variables may be invalid if there is (second or higher order) autocorrelation in the error term. One way to validate the results is to use even further lags of the lagged dependent variable as instruments. Thus, we collect in Column (VI) System-GMM regressions where we only use lags starting from the third lag as an instrument. Overall, the System-GMM results with these alternative instrument sets are again in line with the baseline estimates.

\subsubsection{The election of 2003}

Our sample includes two election years: 2003 and 2008. Since 2003 was an eventful year in the Israeli economy - and for the Israeli municipalities - in a way that could potentially result in higher deficits that are not related to the electoral cycle, we tested whether the variables of interest maintain their effect when we allow for an idiosyncratic effect in $2003 .^{15}$

To account for the possibility that our results are driven by the developments in 2003, we report results where we interact our coefficients of interest with a dummy for 2003. If the regression results were only driven by the 2003 election, we should observe the previous patterns only for these interacted variables. The effect of the remaining elections, on the other hand, and their interactions with "own revenues” should be insignificant. ${ }^{16}$ The results are reported in Table 5. We first observe that the cycles in 2003 were not significantly larger than in 2008. We also find that the interaction of "own revenues" with election years maintains its statistical significance

\footnotetext{
${ }^{15}$ In 2003, the central government adopted a fiscal consolidation plan that included reductions in the transfers to local authorities that were reinstated later in the year, increases in local taxation, predominantly by curtailing exemptions, and a public sector wage cut, including in the municipalities.

${ }^{16}$ The interaction for the external accountants with the election year 2003 is omitted as there was only a small number of external accountants in Jewish municipalities in 2003.
} 
and broadly preserves its size - and that there was no statistically significant difference in its size in 2003. Thus, the main results—deficits in election years are smaller when a larger share of the municipality's revenue is raised locally or when the locality has an external accountant—do not reflect the special circumstances in 2003.

\subsubsection{Jewish and Arab municipalities}

As discussed above, the sample used to obtain our previous results includes only Jewish municipalities. However, a significant number of municipalities are predominantly Arab. While it is not useful to analyze both sets of municipalities jointly as they differ along a number of crucial dimensions ${ }^{17}$, we examine the robustness of our results in a sample that includes both types of municipalities. Results from a replication of the baseline model with such a sample are reported in Table 6. Comparing these results with those reported in Table 3, it can be seen that the estimates of the variables of interest do not depend on whether Arab municipalities are excluded from the sample. However, as outlined above, Arab municipalities seem less relevant to our setting and we therefore did not include them in the baseline regressions.

\subsubsection{Other robustness tests}

In Table 7 we examine the robustness of our results to various changes in the specification. In Column (I) we report the results when the dependent variable is the change in the debt per-capita of each municipality, rather than the log, to ensure that our results are not driven by large percentage changes in the debt of municipalities with small per-capita debts. We find that the results are not sensitive to this change in the specification. In Column (II) we replace the binary variable for the level of debt per-capita with a continuous one, again with no implication for our main results. In Column (III) we replace the share of locally generated revenues with its lagged

\footnotetext{
17 In particular electoral competition and voter turnout in Arab municipalities are strongly influenced by clan-affiliation (Ben Bassat and Dahan, 2012).
} 
value, to account for the possibility that local administrations reduce their tax collection efforts in election years, hence lowering the share of "own revenues”. Our results are not affected by this change. Finally, in Column (IV), we add an interaction between the local unemployment rate and election years, to account for the possibility that cyclical economic developments in the election year affect the deficits. This addition has no effect on the main results. Therefore, our own revenues interaction actually measures the effect of decentralization on electoral manipulation but not of low income or socioeconomic status. In addition to these specifications we also experimented with additional year dummy variables, as "placebo election years"; none of the results relating to these years were statistically significant, nor their interactions with our key variables. This is supportive evidence that we are not in fact measuring some idiosyncratic effects biasing our estimates. Moreover, omitting control variables does not seem to change the findings of our baseline regressions, which is re-assuring as unobserved heterogeneity should also not have a substantial effect in this case (Altonji et al., 2005).

\section{Conclusion}

We study two institutional factors that affect the existence and magnitude of political budget cycles in local governments. Our results suggest that reliance on central government transfers enhances political budget cycles while tight central oversight diminishes them. Local politicians ostensibly restrain electorally motivated deficits if they are likely to be eventually financed by the municipality's residents, but they expand them if they can plausibly expect that future central transfers will cover a significant part of such deficits. These results thus imply that the magnitude of political budget cycles is exacerbated by badly designed fiscal institutions that lead to soft budget constraints. Soft budget constraints may lead incumbents to enhance local 
services or to reduce tax collection efforts during their campaign, speculating that voters would believe that some of the cost will be borne by residents of other municipalities. ${ }^{18}$

These findings imply that politicians take into account that voters are aware of their electoral manipulation and its inefficiency. This observation is consistent with the notion that voters are fiscally conservative (Peltzman, 1992; Brender, 2003; Brender and Drazen, 2008). It is thus an indication that political budget cycles emerge where information is imperfect (as suggested by Shi and Svensson, 2006, among others) or where some of the cost may be shifted to others. This may also suggest that in advanced economies, where information is of higher quality than in developing ones, political budget cycles are more likely to be found in local elections—at least where budget constraints are soft and some of the cost may be expected to be shifted to the central government- than in national ones.

A potential expansion of our results is to countries that receive substantial amounts of foreign aid, either in the form of continuous flows or as part of an IMF loan or other multinational program transfers. Soft budget constraints in such programs-reflected in a willingness to renegotiate the program's terms-may lead politicians in the target countries to "sweeten the pill” in election years, expecting that some of the burden may fall on the donor's shoulders. Since one cannot expect the appointment of external accountants in an international setting, our results may indicate the need for strict enforcement of the original terms of such programs in order to contain the incentives for apolitical budget cycles in the receiving countries.

\footnotetext{
${ }^{18}$ Brender (2003) has shown that, controlling for a large number of performance indicators, voters do not reward mayors who raise more resources from the central government during their term in office. Here, however, we examine the tendency to increase the deficit in election years without conditioning on performance - hence allowing for the possibility that the increased deficits were used to improve municipal services during the campaign.
} 


\section{References}

Aidt, T. S., F. J. Veiga, and L. G. Veiga (2011). Election results and opportunistic policies: A new test of the rational political business cycle model. Public choice, 148(1-2), 21-44.

Akhmedov, A. and E. Zhuavskaya (2004). Opportunistic political cycles: test in a young democracy setting. Quarterly Journal of Economics 119, 1301-1338.

Alesina, A. (1989). Politics and business cycles in industrial democracies. Economic Policy 4, 55-98.

Alesina, A., G. D. Cohen, and N. Roubini (1993). Electoral business cycle in industrial democracies. European Journal of Political Economy 9, 1-23.

Alt, J. E. and D. D. Lassen (2006). Transparency, political polarization, and political budget cycles. American Journal of Political Science 50, 530-550.

Altonji, J., T. Elder, and C. Taber (2005). Selection on observed and unobserved: assessing the effectiveness of Catholic schools. Journal of Political Economy 113, 151-184.

Anderson, T. and C. Hsiao (1981). Estimation of dynamic models with error components. Journal of the American Statistical Association 76, 589-606.

Arellano, M. and S. Bond (1991). Some tests of specification for panel data. Review of Economic Studies 58, 277297.

Baskaran, T. (2012). Soft budget constraints and strategic interactions in subnational borrowing: evidence from the German States, 1975-2005. Journal of Urban Economics 71, 114-127.

Baskaran, T., B. Min, and Y. Uppal (2015). Election cycles and electricity provision: Evidence from a quasi-experiment with Indian special elections. Journal of Public Economics 126, 64-73.

Ben Bassat, A., and M. Dahan (2012). Social identity and voting behavior. Public Choice, 151(1-2), 193-214.

Ben Bassat, A., M. Dahan, and E. F. Klor (2013). Is centralization a solution to the soft budget constraint problem? Mimeo (Hebrew University of Jerusalem).

Blais, A. and R. Nadeau (1992). The electoral budget cycle. Public Choice 74, 389-403.

Blundell, R. and S. Bond (1998). Initial conditions and moment restrictions in dynamic panel data models. Journal of Econometrics 87(1), 115-143.

Blundell, R. and S. Bond (2000). GMM estimation with persistent panel data: An application to production functions. Econometric Reviews 19(3), 321-340.

Brambor, T., W. R. Clark, and M. Golder (2006). Understanding interaction models: improving empirical analyses. Political Analysis 14(1), 63-82. 
Brender, A. (2003). The effect of fiscal performance on local government election results in Israel: 1989-1998. Journal of Public Economics 87, 2187-2205.

Brender, A. and A. Drazen (2005). Political budget cycles in new versus established democracies. Journal of Monetary Economics 52, 1271-1295.

Brender, A. and A. Drazen (2008). How do budget deficits and economic growth affect reelection prospects? Evidence from a large panel of countries, American Economic review 98(5), 2203-2220.

Coelho, C., F. J. Veiga, and L. G. Veiga (2006). Political business cycles in local employment: evidence form Portugal. Economics Letters 93, 82-87.

Cole, S. (2009). Fixing market failures or fixing elections? Agricultural credit in India. American Economic Journal: Applied Economics 1, 219-250.

Cukierman, A. and A. H. Meltzer (1986). A positive theory of discretionary policy, the cost of a democratic government, and the benefits of a constitution. Economic Inquiry 24, 367-388.

Dahlberg, M. and E. Mörk (2011). Is there an election cycle in public employment? separating time effects from election year effects. CESifo Economic Studies 57, 480-498.

De Haan, J. and J. Klomp (2013). Conditional political budget cycles: a review of recent evidence. Public Choice 157, 387-410.

Diskin, A., and A. Eden (1999) "The rational voter in the municipal election in Israel." Floresheimer Studies Press.

Drazen, A. (2008). "Political budget cycles." The New Palgrave Dictionary of Economics, Second Edition. Eds. Steven N. Durlauf and Lawrence E. Blume. Palgrave Macmillan,

Drazen, A. and M. Eslava (2010). Electoral Manipulation via Voter-Friendly Spending: Theory and Evidence, Journal of Development Economics, vol. 92(1), 39-52.

Eslava, M. (2011). The political economy of fiscal deficits: a survey, Journal of Economic Surveys 25(4), 645-673.

Foremny, D., R. Freier, M.D. Moessinger and M. Yeter (2014), Overlapping Political Budget Cycles in the Legislative and the Executive, ZEW Discussion Paper No. 14-099, Mannheim.

Galli, E. and S. Rossi (2002). Political business cycles: the case of the Western German Länder. Public Choice 110, 283-303.

Hillman, A., Metsuyanim, K., and Potrafke, N. (2015). Clan-based Democracy. European Journal of Political Economy (forthcoming).

Judson, R. A. and A. L. Owen (1999). Estimating dynamic panel data models: a guide for macroeconomists. Economics Letters 65, 9-15. 
Khemani, S. (2004). Political cycles in a developing economy: effect of elections in the Indian States. Journal of Development Economics 73, 125-154.

Klein, F. A. and S. N. Sakurai (2015). Term limits and political budget cycles at the local level: evidence from a young democracy. European Journal of Political Economy 37, 21-36.

Kornai, J. (1979). Resource-constrained versus demand-constrained systems. Econometrica 801-819.

Kornai, J. (1986). The soft budget constraint. Kyklos 39(1), 3-30.

Meloni, O. and M. Tommasi (2012). Voters as fiscal liberals: incentives and accountability in federal systems. Economics and Politics 24, 135-156.

Nickell, S. J. (1981). Biases in dynamic models with fixed effects. Econometrica 49(6), 1417-1426.

Nie, H., M. Jiang, and X. Wang (2013). The impact of political cycle: evidence from coalmine accidents in china. Journal of Comparative Economics 41, 995-1011.

Nordhaus, W. (1975). The political business cycle. Review of Economic Studies 42, 169-190.

Peltzman, S. (1992). Voters as fiscal conservatives. Quarterly Journal of Economics 107, 325-345.

Pettersson-Lidbom, P. (2010). Dynamic commitment and the soft budget constraint: an empirical test. American Economic Journal: Economic Policy 2, 154-179.

Reingewertz, Y. (2012). Do municipal amalgamations work? Evidence from municipalities in Israel. Journal of Urban Economics, 72(2), 240-251.

Reingewertz, Y. (2015). Political fragmentation and fiscal status: evidence from Israeli municipalities. Local Government Studies (forthcoming).

Rodden, J. (2002). The dilemma of fiscal federalism: grants and fiscal performance around the world. American Journal of Political Science 46(3), 670-687.

Rodden, J., G. Eskeland, and J. Litvack (2003). Fiscal decentralization and the challenge of hard budget constraints. MIT Press.

Rogoff, K. (1990). Equilibrium political business cycles. American Economic Review 80(21-36).

Rogoff, K. and A. Siber (1988). Elections and macroeconomic policy cycles. Review of Economic Studies 55, 1-16.

Roodman, D. (2008). A note on the theme of too many instruments. Center for Global Development Working Paper.

Rose, S. (2006). Do fiscal rules dampen the political business cycle. Public Choice 128, $207-431$.

Schneider, C. J. (2010). Fighting with one hand tied behind the back: political budget cycles in the West German states. Public Choice 142, 301-314. 
Shi, M. and J. Svensson (2006). Political budget cycles: do they differ across countries and why? Journal of Public Economics 90, 1367-1389.

Sola, S. and G. Palomba (2015). Sub-National Government’s Risk Premia: Does Fiscal Performance Matter? IMF Working Paper WP/15/117

Steklov, O (2008). Local authorities, regulation and in between them. Mimeo.

Tepe, M. and P. Vanhuysse (2014). A vote at the opera? The political economy of public theaters and orchestras in the German states. European Journal of Political Economy 36, 254-273.

Veiga, L. G. and F. J. Veiga (2007). Political business cycles at the municipal level. Public Choice 131, 45-64.

Weingast, B., K. Shepsle, and C. Johnsen (1981). The political economy of costs and benefits: a neoclassical approach to distributive politics. Journal of Political Economy 89(4), 642-664. 
Table 1: Definition of variables

\begin{tabular}{lll}
\hline Variable & Definition & Source \\
\hline Deficit & First difference of log debt per-capita. & MOIN \\
Election & Dummy for election year. & MOIN \\
"own revenues" & Share of locally raised revenue out of total revenue. & MOIN \\
External & Dummy variable capturing if an external accountant was in the & MOIN \\
Population & municipality in a given year. & ICBS \\
Unemployed & Number of unemployed per 1,000 residents. & ICBS \\
High debt & Dummy =1 if debt above the median debt $(3,046)$ in the sample & MOIN \\
Transfers p. c. & used in the regressions, 0 else. & MOIN
\end{tabular}

Note: Data was obtained from the Ministry of Interior (MOIN) and the Israeli Central Bureau of Statistics (ICBS).

Table 2: Summary statistics

\begin{tabular}{lrrrrr}
\hline & $\mathrm{N}$ & Mean & Std.Dev & Min & Max \\
\hline Deficit & 1212 & -0.024 & 0.154 & -0.575 & 0.703 \\
Election & 1202 & 0.190 & 0.392 & 0.000 & 1.000 \\
External & 1212 & 0.076 & 0.265 & 0.000 & 1.000 \\
"own revenues" & 1212 & 0.595 & 0.170 & 0.128 & 0.953 \\
Population (millions) & 1212 & 0.047 & 0.087 & 0.001 & 0.773 \\
Unemployed (out of 1,000 residents) & 1212 & 12.829 & 6.779 & 1.923 & 43.553 \\
High debt & 1212 & 0.515 & 0.500 & 0.000 & 1.000 \\
Transfers p. c. (10,000 NIS) & 1212 & 0.093 & 0.105 & 0.000 & 0.741 \\
\hline
\end{tabular}

Note: This table presents summary statistics for Israeli-Jewish municipalities. The sample includes 114 municipalities for duration of 11 years. Some observations are missing due to missing data. The regressions in the following tables include fewer observations mainly due to lags, and partly due to missing observations for some variables. 
Table 3: Electoral cycles in Israeli Jewish municipalities, 1999-2009, Baseline regressions

\begin{tabular}{|c|c|c|c|c|}
\hline & (I) & (II) & (III) & (IV) \\
\hline \multirow[t]{2}{*}{ Election } & $0.081 * * *$ & $0.094 * * *$ & $0.171 * * *$ & $0.188 * * *$ \\
\hline & {$[0.011]$} & {$[0.011]$} & {$[0.037]$} & {$[0.039]$} \\
\hline \multirow[t]{2}{*}{ External } & $-0.083^{* * *}$ & $-0.048 * * *$ & & $-0.051 * * *$ \\
\hline & {$[0.014]$} & {$[0.014]$} & & {$[0.015]$} \\
\hline \multirow[t]{2}{*}{ Election x External } & & $-0.137 * * *$ & & $-0.140 * * *$ \\
\hline & & [0.029] & & {$[0.027]$} \\
\hline \multirow[t]{2}{*}{ “own revenues" } & $-0.179 * * *$ & & $-0.109 * *$ & $-0.123 * *$ \\
\hline & {$[0.052]$} & & {$[0.051]$} & {$[0.050]$} \\
\hline \multirow[t]{2}{*}{ Election x "own revenues" } & & & $-0.145^{* *}$ & $-0.157 * * *$ \\
\hline & & & {$[0.058]$} & {$[0.061]$} \\
\hline \multirow[t]{2}{*}{ Unemployed } & $0.002^{* *}$ & $0.002 * * *$ & $0.002 * *$ & $0.002 * * *$ \\
\hline & {$[0.001]$} & {$[0.001]$} & {$[0.001]$} & {$[0.001]$} \\
\hline \multirow[t]{2}{*}{ Population } & 0.010 & -0.010 & 0.018 & 0.011 \\
\hline & {$[0.046]$} & {$[0.053]$} & [0.044] & {$[0.047]$} \\
\hline \multirow[t]{2}{*}{ High debt } & $0.074 * * *$ & $0.069 * * *$ & $0.064 * * *$ & $0.073 * * *$ \\
\hline & {$[0.011]$} & {$[0.011]$} & {$[0.011]$} & {$[0.011]$} \\
\hline \multirow[t]{2}{*}{ Transfers p. c. } & $-0.315^{* * *}$ & -0.095 & $-0.291 * * *$ & $-0.280 * * *$ \\
\hline & {$[0.085]$} & {$[0.063]$} & {$[0.092]$} & {$[0.086]$} \\
\hline \multirow[t]{2}{*}{ Trend } & 0.002 & 0.002 & 0.002 & 0.002 \\
\hline & {$[0.002]$} & {$[0.002]$} & {$[0.002]$} & {$[0.002]$} \\
\hline \multirow[t]{2}{*}{$y(t-1)$} & $0.163 * * *$ & $0.163^{* * *}$ & $0.173 * * *$ & $0.154 * * *$ \\
\hline & {$[0.038]$} & {$[0.038]$} & {$[0.039]$} & {$[0.038]$} \\
\hline $\mathrm{N}$ & 1083 & 1083 & 1083 & 1083 \\
\hline Municipalities & 114 & 114 & 114 & 114 \\
\hline $\mathrm{Chi}^{2}$ & 273.610 & 246.823 & 213.644 & 281.238 \\
\hline Hansen-test(p-val.) & 0.282 & 0.252 & 0.273 & 0.332 \\
\hline$A R(1)$-test(p-val.) & 0.000 & 0.000 & 0.000 & 0.000 \\
\hline AR(2)-test(p-val.) & 0.729 & 0.682 & 0.607 & 0.607 \\
\hline Instruments No. & 63 & 63 & 63 & 65 \\
\hline
\end{tabular}


Table 4: Robustness tests with different estimation methods

\begin{tabular}{|c|c|c|c|c|c|c|}
\hline & (I) & (II) & (III) & (IV) & (V) & (VI) \\
\hline \multirow[t]{2}{*}{ Election } & $0.212 * * *$ & $0.170 * * *$ & $0.166 * * *$ & $0.176 * * *$ & $0.182 * * *$ & $0.184^{* * *}$ \\
\hline & {$[0.042]$} & {$[0.039]$} & {$[0.038]$} & {$[0.040]$} & {$[0.041]$} & {$[0.037]$} \\
\hline \multirow[t]{2}{*}{ External } & $-0.062 * * *$ & -0.039 & $-0.073 * * *$ & $-0.057 * * *$ & $-0.052 * * *$ & $-0.045^{* * *}$ \\
\hline & {$[0.021]$} & {$[0.027]$} & {$[0.024]$} & {$[0.014]$} & {$[0.014]$} & {$[0.017]$} \\
\hline \multirow[t]{2}{*}{ Election x External } & $-0.165 * * *$ & $-0.108 * * *$ & $-0.125 * * *$ & $-0.125 * * *$ & $-0.128 * * *$ & $-0.145 * * *$ \\
\hline & {$[0.028]$} & {$[0.027]$} & {$[0.028]$} & {$[0.026]$} & {$[0.027]$} & {$[0.026]$} \\
\hline \multirow[t]{2}{*}{ “own revenues" } & -0.163 & 0.023 & -0.05 & $-0.130 * * *$ & $-0.121 * *$ & $-0.155^{* *}$ \\
\hline & {$[0.175]$} & {$[0.211]$} & [0.224] & {$[0.050]$} & {$[0.050]$} & {$[0.061]$} \\
\hline \multicolumn{7}{|l|}{ Election $\mathrm{x}$ "own } \\
\hline \multirow[t]{2}{*}{ revenues" } & $-0.208 * * *$ & $-0.133 * *$ & $-0.122 * *$ & $-0.144 * *$ & $-0.148 * *$ & $-0.163 * * *$ \\
\hline & {$[0.065]$} & {$[0.061]$} & [0.059] & {$[0.062]$} & {$[0.062]$} & {$[0.059]$} \\
\hline \multirow[t]{2}{*}{ Unemployed } & 0.002 & $0.009 * * *$ & $0.005^{* * *}$ & $0.002 * * *$ & $0.002 * * *$ & $0.002 * *$ \\
\hline & {$[0.001]$} & {$[0.002]$} & {$[0.002]$} & {$[0.001]$} & {$[0.001]$} & {$[0.001]$} \\
\hline \multirow[t]{2}{*}{ Population } & -0.299 & -1.364 & -1.057 & 0.011 & 0.012 & 0.021 \\
\hline & {$[0.677]$} & [1.251] & [1.337] & [0.049] & {$[0.048]$} & [0.050] \\
\hline \multirow[t]{2}{*}{ High debt } & $0.078 * * *$ & $0.133^{* * *}$ & $0.133 * * *$ & $0.074 * * *$ & $0.073 * * *$ & $0.080 * * *$ \\
\hline & {$[0.016]$} & {$[0.020]$} & {$[0.021]$} & {$[0.011]$} & {$[0.011]$} & {$[0.012]$} \\
\hline \multirow[t]{2}{*}{ Transfers p. c. } & $-0.450 *$ & $-0.719 * *$ & $-0.706 * *$ & $-0.290 * * *$ & $-0.276^{* * *}$ & $-0.332 * * *$ \\
\hline & {$[0.231]$} & {$[0.342]$} & {$[0.294]$} & {$[0.090]$} & {$[0.086]$} & {$[0.098]$} \\
\hline \multirow[t]{2}{*}{ Trend } & -0.002 & & 0.003 & $0.004 * *$ & 0.003 & 0.002 \\
\hline & {$[0.003]$} & & {$[0.004]$} & {$[0.002]$} & {$[0.002]$} & {$[0.002]$} \\
\hline \multirow[t]{2}{*}{$y(t-1)$} & 0.047 & 0.087 & $0.114^{* *}$ & $0.179 * * *$ & $0.160 * * *$ & -0.015 \\
\hline & {$[0.036]$} & {$[0.158]$} & {$[0.045]$} & {$[0.042]$} & {$[0.041]$} & [0.117] \\
\hline \multirow[t]{2}{*}{ Estimation method } & Within FE & Anderson- & Difference & System & System & System \\
\hline & & Hsiao & GMM & GMM & GMM & GMM \\
\hline Type of instrument & & $\begin{array}{l}\text { 2nd lag of } \\
\text { difference }\end{array}$ & $\begin{array}{l}\text { Full } \\
\text { instrument } \\
\text { set }\end{array}$ & Collapsed & 1-2 Lag & 3 - N Lag \\
\hline $\mathrm{N}$ & 1083 & 854 & 968 & 1083 & 1083 & 1083 \\
\hline Municipalities & 114 & 113 & 113 & 114 & 114 & 114 \\
\hline $\mathrm{Chi}^{2}$ & & & 189.287 & 280.561 & 251.554 & 204.360 \\
\hline $\mathrm{F}$ & 22 & 16 & & & & \\
\hline Hansen-test(p-val.) & & & 0.242 & 0.108 & 0.04 & 0.292 \\
\hline AR(1)-test(p-val.) & & & 0.000 & 0.000 & 0.000 & 0.002 \\
\hline$A R(2)$-test(p-val.) & & & 0.997 & 0.479 & 0.58 & 0.334 \\
\hline Instruments No. & & 1 & 55 & 21 & 37 & 46 \\
\hline
\end{tabular}

Notes: Dependent variable: growth rate in log debt per-capita (deficit). Models (I) is estimated with the standard within fixed effects estimator. Model (II) is estimated with Anderson-Hsiao using as instrument for the first difference of the lagged dependent variable its second lag of the first difference (Model II). Models (III) is estimated with Difference-GMM using the full instrument set. Model (IV) is estimated with System-GMM using the collapsed instrument set. Model $(\mathrm{V})$ is estimated with System-GMM using up to the second lag of the lagged dependent variable as instrument. Model (VI) is estimated using all lags starting from the third as instruments. Stars indicate significance levels at $10 \%(*), 5 \%(* *)$ and $1 \%(* * *)$. Standard errors are reported in parentheses. All models with cluster and heteroscedasticity robust standard errors. 
Table 5: The elections of 2003

\begin{tabular}{|c|c|c|c|c|}
\hline & (I) & (II) & (III) & (IV) \\
\hline \multirow[t]{2}{*}{ Election } & $0.109 * *$ & $0.147^{* * *}$ & $0.103 * *$ & $0.120 * *$ \\
\hline & {$[0.046]$} & {$[0.056]$} & {$[0.047]$} & {$[0.054]$} \\
\hline \multirow[t]{2}{*}{ Election x 2003} & 0.095 & 0.002 & 0.072 & 0.142 \\
\hline & [0.091] & [0.098] & [0.095] & [0.093] \\
\hline \multirow[t]{2}{*}{ External } & $-0.058 * * *$ & -0.042 & $-0.068 * * *$ & $-0.063 * * *$ \\
\hline & {$[0.014]$} & {$[0.027]$} & {$[0.024]$} & {$[0.021]$} \\
\hline \multirow[t]{2}{*}{ Election x External } & $-0.084 * * *$ & $-0.077 * * *$ & $-0.073 * *$ & $-0.117 * * *$ \\
\hline & {$[0.028]$} & [0.029] & {$[0.029]$} & {$[0.030]$} \\
\hline \multirow[t]{2}{*}{ "own revenues" } & $-0.120 * *$ & 0.039 & -0.029 & -0.164 \\
\hline & [0.049] & [0.209] & {$[0.221]$} & {$[0.176]$} \\
\hline \multicolumn{5}{|l|}{ Election x "own } \\
\hline \multirow[t]{2}{*}{ revenues" } & $-0.124 *$ & $-0.157^{*}$ & -0.105 & $-0.142 *$ \\
\hline & {$[0.072]$} & {$[0.082]$} & {$[0.072]$} & {$[0.080]$} \\
\hline \multicolumn{5}{|l|}{ Election x "own } \\
\hline \multirow[t]{2}{*}{ revenues" x 2003} & 0.014 & 0.111 & 0.039 & -0.083 \\
\hline & [0.141] & [0.147] & [0.144] & {$[0.137]$} \\
\hline \multirow[t]{2}{*}{ Population } & 0.016 & -1.662 & -1.275 & -0.403 \\
\hline & {$[0.045]$} & [1.330] & [1.380] & {$[0.664]$} \\
\hline \multirow[t]{2}{*}{ Unemployed } & $0.002 * * *$ & $0.007^{* * *}$ & $0.005^{* * *}$ & 0.001 \\
\hline & {$[0.001]$} & {$[0.002]$} & {$[0.002]$} & {$[0.001]$} \\
\hline \multirow[t]{2}{*}{ High debt } & $0.068 * * *$ & $0.129 * * *$ & $0.128 * * *$ & $0.073 * * *$ \\
\hline & {$[0.010]$} & {$[0.020]$} & {$[0.020]$} & {$[0.016]$} \\
\hline \multirow[t]{2}{*}{ Transfers p. c. } & $-0.245^{* * *}$ & $-0.605^{*}$ & $-0.525^{*}$ & $-0.374 *$ \\
\hline & {$[0.083]$} & {$[0.351]$} & {$[0.286]$} & {$[0.220]$} \\
\hline \multirow[t]{2}{*}{ Trend } & $0.005^{* * *}$ & & 0.007 & 0.001 \\
\hline & {$[0.002]$} & & {$[0.004]$} & {$[0.003]$} \\
\hline \multirow[t]{2}{*}{$y(t-1)$} & $0.163^{* * *}$ & 0.106 & $0.131^{* * *}$ & 0.055 \\
\hline & {$[0.039]$} & {$[0.156]$} & {$[0.046]$} & {$[0.036]$} \\
\hline Type of instrument & $\begin{array}{l}\text { System-GMM, full } \\
\text { instrument set }\end{array}$ & Anderson-Hsiao & $\begin{array}{l}\text { Difference GMM, } \\
\text { full instrument } \\
\text { set }\end{array}$ & Within FE \\
\hline $\mathrm{N}$ & 1,083 & 854 & 968 & 1083 \\
\hline $\mathrm{Chi}^{2}$ & 310.122 & & 212.52 & \\
\hline $\mathrm{F}$ & & 14.718 & & 19.893 \\
\hline Hansen-test(p-val.) & 0.385 & & 0.262 & \\
\hline AR(1)-test(p-val.) & 0.000 & & 0.000 & \\
\hline AR(2)-test(p-val.) & 0.875 & & 0.802 & \\
\hline Instruments No. & 67 & 1 & 57 & \\
\hline
\end{tabular}

Notes: Dependent variable: growth rate in log debt per-capita (deficit). Model (I) is estimated with the standard System-GMM estimator. Model (II) is estimated with the Anderson-Hsiao estimator using the second lag of the first difference as instrument for the lagged dependent variable. Models (III) is estimated with Difference-GMM using the full instrument set. Model (IV) is estimated with the standard fixed effects estimator. Stars indicate significance levels at $10 \%(*), 5 \%\left({ }^{* *}\right)$ and $1 \%(* * *)$. Standard errors are reported in parentheses. All models with cluster and heteroscedasticity robust standard errors. 
Table 6: Electoral cycles in Israeli municipalities, 1999-2009, replication with all municipalities (Jewish and Arab)

\begin{tabular}{|c|c|c|c|c|}
\hline & (I) & (II) & (III) & (IV) \\
\hline \multirow[t]{2}{*}{ Election } & $0.088 * * *$ & $0.113^{* * *}$ & $0.156 * * *$ & $0.189 * * *$ \\
\hline & {$[0.009]$} & {$[0.011]$} & {$[0.024]$} & {$[0.028]$} \\
\hline \multirow[t]{2}{*}{ External } & $-0.095^{* * *}$ & $-0.040 * * *$ & & $-0.065 * * *$ \\
\hline & {$[0.012]$} & {$[0.012]$} & & {$[0.012]$} \\
\hline \multirow[t]{2}{*}{ Election x External } & & $-0.128 * * *$ & & $-0.135 * * *$ \\
\hline & & {$[0.024]$} & & {$[0.024]$} \\
\hline \multirow[t]{2}{*}{ “own revenues" } & $-0.302 * * *$ & & $-0.210 * * *$ & $-0.255^{* * *}$ \\
\hline & {$[0.038]$} & & {$[0.034]$} & {$[0.036]$} \\
\hline \multirow[t]{2}{*}{ Election x "own revenues" } & & & $-0.122 * * *$ & $-0.156 * * *$ \\
\hline & & & {$[0.043]$} & {$[0.047]$} \\
\hline \multirow[t]{2}{*}{ Unemployed } & 0.001 & -0.001 & 0.001 & $0.001 *$ \\
\hline & {$[0.001]$} & {$[0.001]$} & {$[0.001]$} & [0.001] \\
\hline \multirow[t]{2}{*}{ Population } & 0.013 & -0.103 & 0.029 & 0.012 \\
\hline & {$[0.047]$} & {$[0.064]$} & [0.043] & [0.047] \\
\hline \multirow[t]{2}{*}{ High debt } & $0.089 * * *$ & $0.071 * * *$ & $0.070 * * *$ & $0.084 * * *$ \\
\hline & {$[0.010]$} & {$[0.011]$} & {$[0.010]$} & {$[0.010]$} \\
\hline \multirow[t]{2}{*}{ Transfers p. c. } & $-0.486 * * *$ & -0.069 & $-0.431 * * *$ & $-0.446 * * *$ \\
\hline & {$[0.087]$} & {$[0.058]$} & {$[0.088]$} & {$[0.086]$} \\
\hline \multirow[t]{2}{*}{ Trend } & -0.001 & $-0.005^{* *}$ & $-0.006 * * *$ & -0.001 \\
\hline & {$[0.002]$} & {$[0.002]$} & {$[0.002]$} & {$[0.002]$} \\
\hline \multirow[t]{2}{*}{$y(t-1)$} & $0.154^{* * *}$ & $0.166^{* * *}$ & $0.167 * * *$ & $0.148 * * *$ \\
\hline & {$[0.031]$} & {$[0.031]$} & {$[0.031]$} & {$[0.031]$} \\
\hline $\mathrm{N}$ & 1751 & 1751 & 1751 & 1751 \\
\hline Municipalities & 188 & 188 & 188 & 188 \\
\hline $\mathrm{Chi}^{2}$ & 467.646 & 377.938 & 372.597 & 494.136 \\
\hline Hansen-test(p-val.) & 0.011 & 0.019 & 0.011 & 0.085 \\
\hline$A R(1)$-test(p-val.) & 0.000 & 0.000 & 0.000 & 0.000 \\
\hline AR(2)-test(p-val.) & 0.902 & 0.762 & 0.902 & 0.697 \\
\hline Instruments No. & 63 & 63 & 63 & 65 \\
\hline
\end{tabular}


Table 7: Electoral cycles in Israeli Jewish municipalities, 1999-2009, Various robustness tests

\begin{tabular}{|c|c|c|c|c|}
\hline & $(\mathrm{I})$ & (II) & (III) & (IV) \\
\hline \multirow[t]{2}{*}{ Election } & $688.129 * * *$ & $0.185^{* * *}$ & $0.197 * * *$ & $0.144^{* * *}$ \\
\hline & [206.839] & {$[0.039]$} & {$[0.041]$} & $(0.043)$ \\
\hline \multirow[t]{2}{*}{ External } & $-346.418 * * *$ & $-0.061 * * *$ & $-0.051 * * *$ & $-0.053 * * *$ \\
\hline & [80.572] & {$[0.014]$} & {$[0.015]$} & $(0.015)$ \\
\hline \multirow[t]{2}{*}{ Election $x$ External } & $-679.359 * * *$ & $-0.134 * * *$ & $-0.149 * * *$ & $-0.135 * * *$ \\
\hline & [189.210] & {$[0.026]$} & {$[0.029]$} & $(0.028)$ \\
\hline \multirow[t]{2}{*}{ Own revenues } & $-980.547 * * *$ & $-0.171 * * *$ & -0.129 & $-0.124 * *$ \\
\hline & {$[335.425]$} & {$[0.054]$} & {$[0.080]$} & $(0.050)$ \\
\hline \multirow[t]{2}{*}{ Election $x$ Own revenues } & $-605.975^{* *}$ & $-0.154 * * *$ & $-0.176 * * *$ & $-0.143 * *$ \\
\hline & [304.018] & {$[0.060]$} & {$[0.063]$} & $(0.059)$ \\
\hline \multirow[t]{2}{*}{ Population } & -86.92 & -0.042 & 0.021 & 0.013 \\
\hline & [164.180] & {$[0.049]$} & {$[0.042]$} & {$[0.048]$} \\
\hline \multirow[t]{2}{*}{ Unemployed } & $5.394^{*}$ & $0.001^{*}$ & $0.002 * * *$ & $0.002 * *$ \\
\hline & {$[3.146]$} & {$[0.001]$} & {$[0.001]$} & $(0.001)$ \\
\hline \multirow[t]{2}{*}{ Election x Unemployed } & & & & 0.003 \\
\hline & & & & $(0.002)$ \\
\hline \multirow[t]{2}{*}{ High debt } & $123.232^{* * *}$ & & $0.072 * * *$ & $0.071 * * *$ \\
\hline & {$[36.280]$} & & {$[0.011]$} & $(0.011)$ \\
\hline \multirow[t]{2}{*}{ Transfers p. c. } & $-2,001.021 * * *$ & $-0.432 * * *$ & $-0.283^{* *}$ & $-0.276^{* * *}$ \\
\hline & {$[523.738]$} & {$[0.107]$} & {$[0.134]$} & {$[0.085]$} \\
\hline \multirow[t]{2}{*}{ Debt pc. } & & $0.070 * * *$ & & \\
\hline & & {$[0.010]$} & & \\
\hline \multirow[t]{2}{*}{ Trend } & 3.134 & 0.001 & 0.003 & 0.003 \\
\hline & [6.394] & {$[0.002]$} & {$[0.002]$} & $(0.002)$ \\
\hline \multirow[t]{2}{*}{$y(t-1)$} & $0.159^{*}$ & $0.149 * * *$ & $0.153^{* * *}$ & $0.153^{* * *}$ \\
\hline & {$[0.092]$} & {$[0.037]$} & {$[0.038]$} & $(0.038)$ \\
\hline $\mathrm{N}$ & 1083 & 1083 & 1083 & 1083 \\
\hline Municipalities & 114 & 114 & 114 & 114 \\
\hline $\mathrm{Chi}^{2}$ & 153.381 & 268.040 & 263.773 & 285.698 \\
\hline Hansen-test(p-val.) & 0.010 & 0.200 & 0.314 & 0.324 \\
\hline$A R(1)$-test(p-val.) & 0.000 & 0.000 & 0.000 & 0.000 \\
\hline$A R(2)$-test(p-val.) & 0.741 & 0.529 & 0.731 & 0.63 \\
\hline Instruments No. & 65 & 65 & 65 & 66 \\
\hline
\end{tabular}

Notes: This table collects results from four robustness tests. In column (I), we use as dependent variable the annual difference in debt per-capita. In column (II), we replace the dummy for high debt with the raw debt per-capita. In column (III), we replace own revenues with lagged own revenues. In column (IV), we additionally control for an interaction between the election dummy and the unemployment rate. 